Perbedaan Hasil Belajar Peserta Didik Kelas XI MIA SMAN 9 Gowa yang diajar Model Problem Based Learning dan Discovery Learning (Studi pada Materi Pokok Asam Basa)

\title{
Perbedaan Hasil Belajar Peserta Didik Kelas XI MIA SMAN 9 Gowa yang diajar Model Problem Based Learning dan Discovery Learning (Studi pada Materi Pokok Asam Basa)
}

\author{
Comparison of Learning Outcomes in Class XI MIA SMAN 9 Gowa that \\ taught using Problem Based Learning and Discovery Learning Models (Study \\ of Acid-Base Subject Matter) \\ ${ }^{1)}$ Anugrawati Asri, ${ }^{2)}$ Halimah Husain, ${ }^{3)}$ Sugiarti \\ ${ }^{123)}$ Jurusan Kimia Fakultas Matematika dan Ilmu Pengetahuan Alam \\ Universitas Negeri Makassar, Jl. Dg Tata Raya Makassar, Makassar 90224 \\ Email:anugrawati.asri01@gmail.com
}

\begin{abstract}
ABSTRAK
Penelitian ini adalah penelitian eksperimen semu yang bertujuan membandingkan hasil belajar peserta didik yang diajar model Problem Based Learning (PBL) dan Discovery Learning pada materi pokok asam basa. Desain penelitian yang digunakan adalah posttest only two group design. Populasi penelitian ini adalah peserta didik kelas XI MIA SMAN 9 Gowa yang berjumlah 204 peserta didik yang tersebar dalam 6 kelas. Pengambilan sampel dilakukan secara random sampling. Kelas yang tepilih sebagai sampel yaitu kelas yaitu kelas XI MIA 3 sebagai kelas eksperimen I (PBL) dan kelas XI MIA 6 sebagai kelas eksperimen II (Discovery Learning) dengan jumlah peserta didik masing-masing sebanyak 34 orang. Data penelitian diperoleh melalui tes hasil belajar. Data hasil belajar dianalisis dengan menggunakan statistik deskriptif dan statistik inferensial. Data rata-rata hasil belajar kelas eksperimen I sebesar 70,97 dan kelas eksperimen II sebesar 63,31. Data hasil analisis inferensial terhadap hasil belajar peserta didik menujukkan bahwa data hasil belajar peserta didik untuk kelas eksperimen I dan II tidak terdisribusi normal dan berasal dari varian homogen. Hasil pengujian hipotesis menggunakan uji mann-whitney diperoleh $Z_{\text {hitung }}>Z_{\text {tabel }}(8,66>1,64)$. Hal tersebut menunjukkan terdapat perbedaan antara hasil belajar peserta didik yang dibelajarkan model PBL dengan Discovery Learning pada materi pokok asam basa.
\end{abstract}

Kata Kunci: Hasil Belajar, Problem Based Learning (PBL), Discovery Learning

\begin{abstract}
This research was quasi experiment research that aimed to know differences learning outcomes of student that taught using Problem Based Leaning (PBL) and Discovery Learning Models. Desain of research is posttest - only two group design. Population was students in class XI MIA SMAN 9 Gowa that consisted of 204 students with six classes. Sample was taken randomly. The sample research consisted of two classes, namely XI
\end{abstract}


Perbedaan Hasil Belajar Peserta Didik Kelas XI MIA SMAN 9 Gowa yang diajar Model Problem Based Learning dan Discovery Learning (Studi pada Materi Pokok Asam Basa)

MIA 3 class as an experiment I (PBL) and XI MIA 6 class as an experiment II (Discovery Learning), each class consisted of 34 students. Research data obtained from learning outcomes test and observation sheets. Data that obtained analyzed by descriptive and inferential statistic. Data of learning outcomes showed that the mean score of experiment I was 70,97 and experiment II was 63,31. The result of analysis inferential from learning outcomes showed that data students learning outcomes in class experiment I adan II was not normally distributed and it has homogen varians, The results of hypothesis testing using Mann-Whitney test values obtained $Z_{\text {calculated }}>Z_{\text {table }}(8,66>1,64)$. It showed that there is differences of learning outcomes from student that taught using PBL and Discovery Learning Model on acid-base subject matter.

Keywords: Learning Outcomes, Problem Based Learning (PBL), Discovery Learning

\section{PENDAHULUAN}

Kimia merupakan salah satu mata pelajaran yang diajarkan dalam peminatan MIPA untuk jenjang pendidikan SMA/MA dan hasil belajar di sekolah masih tergolong rendah. Pelajaran kimia merupakan subjek yang berhubungan erat dengan penanaman suatu konsep. Antara konsep yang satu dengan konsep yang lain dapat saling berhubungan sehingga membentuk hierarki konsep.

Salah satu pokok bahasan kimia yaitu asam basa. Beberapa karakteristik yang dimiliki oleh materi asam basa yaitu memiliki konsep yang relatif banyak sehingga butuh pemahaman peserta didik dalam memahami konsep-konsep asam basa tersebut. dan tidak merasakan manfaat dari pembelajaran asam-basa.

Berdasarkan hasil observasi

yang dilakukan peneliti melalui wawancara kepada guru kimia tentang proses pembelajaran di SMAN 9 Gowa yaitu, saat ini model pembelajaran yang diterapkan guru yaitu model Discovery Learning. Model Discovery Learning yaitu kegiatan pembelajaran yang dapat mengaktifkan peserta didik dan berorientasi pada penemuan. Namun nyatanya penerapan model ini masih belum maksimal. Dari hasil observasi menunjukkan bahwa hasil belajar peserta didik masih rendah.

Rendahnya hasil belajar peserta didik dikarenakan peserta didik masih merasa asing dengan penerapan model pembelajaran Discovery Learning yang menuntut peserta didik untuk melakukan penemuan. Sehingga peserta didik bingung dan kurang termotivasi untuk melakukan penemuannya sendiri. Hal tersebut membuat peserta didik bosan untuk belajar, kurang menarik dan akhirnya malas belajar. Artinya kemampuan kemandirian pesera didik untuk melakukan penemuan memecahkan masalah masih kurang. Dari permasalahan tersebut peneliti mencoba membandingkan model pembelajaran Discovery Learning dengan model lain yang juga dapat mengaktifkan dan mengarahkan peserta didik untuk memecahkan masalah. Dalam penelitan ini model yang 
Perbedaan Hasil Belajar Peserta Didik Kelas XI MIA SMAN 9 Gowa yang diajar Model Problem Based Learning dan Discovery Learning (Studi pada Materi Pokok Asam Basa)

dibandingkan yaitu model Problem Based Learning.

\section{Model Problem Based}

Learning (PBL) adalah sebuah model pembelajaran yang berorientasikan pada peran aktif peserta didik dengan cara menghadapkan peserta didik pada suatu permasalahan dengan tujuan peserta didik mampu untuk menyelesaikan masalah yang ada dan menarik kesimpulan dengan menentukan sendiri langkahnya (Mangun, 2013). Kelebihan model PBL yaitu membentuk agar peserta didik mengembangkan kemampuan berfikir dan memecahkan masalah. Model pembelajaran ini tepat digunakan pada materi asam basa karena pada prisipnya Problem Based Learning menempatkan masalah yang terkait dunia nyata pada awal pembelajaran untuk memotivasi peserta didik, sehingga peserta didik dalam memecahkan permasalahan dapat menghubungkan materi asam basa terhadap kehidupan sekitar.

$$
\text { Model Discovery }
$$

Learning peserta didik didorong untuk belajar sebagian besar melalui keterlibatan aktif mereka sendiri dengan konsep dan prinsip-prinsip yang ada, serta guru mendorong peserta didik untuk memiliki pengalaman dan melakukan sesuatu percobaan yang memungkinkan mereka menemukan prinsip untuk diri mereka sendiri. Pembelajaran dengan Discovery Learning memacu keinginan mengetahui sesuatu dan dapat memberikan motivasi pada peserta didik, memecahkan masalah secara mandiri dan memiliki keterampilan berpikir kritis karena mereka selalu menganalisis dan menangani informasi
( Uno dan Nurdin, 2011 Kelebihan model ini dapat menyebabkan ingatan peserta didik bertahan lama dan mampu merangsang peserta didik dalam menganalisis suatu persoalan kehidupan sehari-hari yang terkait materi asam basa. Dalam proses pembelajaran ini peserta didik dihadapkan pada sesuatu yang menimbulkan rasa ingin tahu, kemudian dilanjutkan untuk tidak memberi generalisasi, agar timbul keinginan untuk menyelidiki sendiri.

Model Problem Based Learning dan model Discovery Learning pada dasarnya memiliki kesamaan yaitu mengacu pada pemecahan situasi masalah yang dapat mengaktifkan peserta didik untuk memecahkannya, maka penerapannya secara garis besar sama. Namun model pembelajaran Discovery Learning sangat menekankan proses penemuan peserta didik secara mandiri. Sedangkan model Problem Based Learning lebih terfokus dan terarah bagaimana peserta didik terampil dalam mencari informasi penting yang dapat mendefinisikan pemecahan masalah secara jelas. Dalam penelitian ini akan dibandingkan pencapaian hasil belajar peserta didik menggunakan kedua model pembelajaran tersebut. Perbandingan penggunaan kedua model pembelajaran ini dapat menunjukkan model pembelajaran mana yang lebih efektif digunakan untuk menujang hasil belajar peserta didik pada pembelajaran kimia materi pokok asam basa.

Berdasarkan dari latar belakang masalah tersebut maka dilakukan penelitian dengan judul 
Perbedaan Hasil Belajar Peserta Didik Kelas XI MIA SMAN 9 Gowa yang diajar Model Problem Based Learning dan Discovery Learning (Studi pada Materi Pokok Asam Basa)

penelitian yaitu "Perbandingan Hasil Belajar Peserta Didik Kelas XI MIA SMAN 9 Gowa yang diajar Model Pembelajaran Prolem Based Learning dan Discovery Learning (studi pada materi pokok asam basa)".

\section{METODE PENELITIAN}

Jenis penelitian ini adalah penelitian pengembangan (research and development). Pengembangan yang dilakukan pada penelitian ini adalah pengembangan penuntun praktikum kimia organik pada pembuatan bioetanol berbasis lingkungan yang mengikuti model penelitian pengembangan perangkat pembelajaran oleh Plomp.

Penelitian ini merupakan penelitian komparasi dengan metode quasi eksperimen. Desain penelitian yang digunakan dalam penelitian ini adalah posttest-only two group design. Variabel yang digunakan dalam penelitian ini terdiri dari variabel bebas dan variabel terikat. Variabel bebas yaitu model pembelajaran Problem Based Learning dan Discovery sedangkan variabel terikatnya adalah hasil belajar peserta didik pada materi pokok asam basa.

Penelitian ini dilaksanakan di SMAN 9 Gowa pada semester genap tahun pelajaran 2018/2019. Populasi dalam penelitian ini adalah seluruh peserta didik kelas XI MIA SMAN 9 Gowa tahun pelajaran 2018/2019 yang terdiri dari enam kelas dengan jumlah peserta didik 204 orang. Sampel dalam penelitian ini ditentukan dengan menggunakan teknik simple random sampling. Dari hasil random tersebut telah dipilih dua kelas, yaitu kelas XI
MIA 3 sebagai kelas eksperimen I serta kelas XI MIA 6 sebagai kelas eksperimen II. Kedua kelas masingmasing terdiri dari 34 peserta didik.

Instrumen yang digunakan dalam penelitian ini terdiri dari instrumen lembar tes hasil belajar peserta didik pada materi pokok asam basa yang diberikan pada akhir pertemuan sebagai posttest. Selain menggunakan tes, data dikumpulkan dari observasi keterlaksanaan pembelajaran sebagai data penunjang. Analisis data dilakukan secara statistik deskriptif dan statistik inferensial. Analisis deskriptif digunakan untuk mendeskripsikan atau memberikan gambaran umum mengenai pencapaian hasil belajar peserta didik pada kelas eksperimen I maupun kelas eksperimen II berupa mean, nilai tertinggi, nilai terendah dan standar deviasi. Analisis statistik inferensial digunakan untuk menguji hipotesis dengan menggunakan statistik non-parametrik Mann Whitney.

Pada penelitian ini, pengujian hipotesis dilakukan dengan menggunakan uji mann-whitney dengan rumus:

Dimana:

$$
\begin{aligned}
& H_{0}: \mu_{1}=\mu_{2} \\
& H_{1}: \mu_{1} \neq \mu_{2}
\end{aligned}
$$

$\mu_{1}=$ rata- rata nilai posttest kelas eksperimen I

$\mu_{2}=$ rata- rata nilai posttest kelas eksperimen II

$\mathrm{H}_{0}=$ Tidak ada perbedaan hasil belajar peserta didik yang dibelajarkan melalui model pembelajaran PBL dengan Discovery 
Perbedaan Hasil Belajar Peserta Didik Kelas XI MIA SMAN 9 Gowa yang diajar Model Problem Based Learning dan Discovery Learning (Studi pada Materi Pokok Asam Basa)

$\mathrm{H}_{1}=$ Terdapat perbedaan hasil belajar peserta didik yang diajar melalui model pembelajaran PBL dengan Discovery.

HASIL DAN PEMBAHASAN

A. Hasil Penelitian

1. Analisis Statistik Deskriptif

Berdasarkan analisis deskrptif

tes hasil belajar peserta didik pada kelas

XI MIA 3 dan XI MIA 6 SMAN 9

Gowa pada semester genap tahun ajaran 2018/2019, setelah melalui proses pembelajaran dengan menggunakan model PBL pada kelas eksperimen I (XI MIA 3) dan menggunakan model Discovery Learning pada kelas ekperimen II (XI MIA 6). Diperoleh data tes hasil belajar seperti pada Tabel 1.

Tabel 1. Hasil Belajar Peserta Didik Kelas Ekperimen PBL dan Discovery

\begin{tabular}{llcc}
\hline No. & Statistik & \multicolumn{2}{c}{ Nilai Statistik } \\
\cline { 3 - 4 } & & Eksperimen I & Eksperimen II \\
\hline 1. & Jumlah Peserta Didik & 34 & 34 \\
2. & Nilai Tertinggi & 90 & 80 \\
3. & Nilai Terendah & 45 & 40 \\
4. & Rata-rata & 70,97 & 63,31 \\
5. & Standar Deviasi & 11,99 & 11,29 \\
\hline
\end{tabular}

Hasil belajar peserta didik kemudian dikelaskan berdasarkan kriteria nilai ketuntasan hasil belajar peserta didik diperoleh data frekuensi dan persentase ketuntasan hasil belajar peserta didik seperti pada Tabel 2 .

Tabel 2. Frekuensi dan Ketumtasan Hasil Belajar Peserta Didik Kelas PBL dan Discovery Learning

\begin{tabular}{|c|c|c|c|c|c|}
\hline \multirow{2}{*}{ Kategori } & \multirow{2}{*}{ Nilai } & \multicolumn{2}{|c|}{ Kelas Eksperimen I } & \multicolumn{2}{|c|}{ Kelas Experimen II } \\
\hline & & Frekuensi & Persentase & Frekuensi & Persentase \\
\hline Tuntas & $\geq 75$ & 19 & $55,89 \%$ & 11 & $32,35 \%$ \\
\hline Tidak Tuntas & $<75$ & 15 & $44,11 \%$ & 23 & $67,65 \%$ \\
\hline \multicolumn{2}{|c|}{ Jumlah } & 34 & $100 \%$ & 34 & $100 \%$ \\
\hline \multicolumn{3}{|c|}{$\begin{array}{l}\text { 2. Pengujian Prasyarat Analisis } \\
\text { Berdasarkan pengujian analisis } \\
\text { prasyarat (uji normalitas dan uji } \\
\text { homogenitas), dinyatakan bahwa data dari } \\
\text { kelas eksperimen I dan kelas eksperimen II } \\
\text { tidak terdistribusi normal dan berasal dari } \\
\text { populasi yang homogen, maka pengujian } \\
\text { hipotesis dilakukan dengan menggunakan }\end{array}$} & \multicolumn{3}{|c|}{$\begin{array}{l}\text { statistik non parametrik (uji mann- } \\
\text { whitney). Berdasarkan hasil perhitungan, } \\
\text { diperoleh nilai } Z_{\text {hitung }}=8,66 \text { dan nilai } Z_{\text {tabel }} \\
\text { pada taraf kepercayaan }(\alpha)=0,05 \text { yaitu } \\
\text { 1,64. maka } \mathrm{H}_{1} \text { diterima dan } \mathrm{H}_{0} \text { ditolak. } \\
\text { Dengan demikian, ditarik kesimpulan } \\
\text { bahwa terdapat perbedaan hasil belajar } \\
\text { peserta didik kelas XI MIA SMAN } 9\end{array}$} \\
\hline
\end{tabular}


Perbedaan Hasil Belajar Peserta Didik Kelas XI MIA SMAN 9 Gowa yang diajar Model Problem Based Learning dan Discovery Learning (Studi pada Materi Pokok Asam Basa)

Gowa yang diajar melalui model PBL dan Discovery Learning ada materi pokok asam basa karena $\mathrm{z}_{\mathrm{hitung}}(3,51)>$ $\mathrm{z}_{\text {tabel }}(1,64)$.

\section{B. Pembahasan}

Penelitian ini dilakukan pada kelas XI MIA SMAN 9 Gowa, dengan kelas XI MIA 3 sebagai kelas experimen I yang menggunakan model pembelajaraan PBL dan kelas XI MIA 6 sebagai kelas experimen II menggunakan model pembelajaran Discovery Learning. Penelitian ini bertujuan melihat perbedaan hasil belajar peserta didik yang diajarkan melalui model pembelajaran Problem Based Learning dengan Discovery Learning dengan pokok bahasan asam basa.

Hasil analisis deskriptif menunjukkan ada perbedaan hasil belajar antara kelas eksperimen I dan kelas eksperimen II, sebagaimana ditunjukkan pada Tabel 1. Berdasarkan Tabel 1, diketahui bahwa nilai rata-rata hasil belajar peserta didik kelas eksperimen I $(70,97)$ lebih tinggi dibandingkan nilai rata-rata hasil belajar peserta didik kelas eksperimen II $(63,31)$.

Hasil analisis deskriptif juga menyajikan persentase ketuntasan kelas. Berdasarkan kriteria ketuntasan hasil belajar peserta didik pada Tabel 2 , ketuntasan hasil belajar peserta didik pada materi asam basa untuk kelas eksperimen I adalah sebanyak 19 orang memenuhi kriteria ketuntasan dengan persentase sebesar $55,89 \%$ dan pada kelas eksperimen II terdapat 11 orang yang tuntas dengan persentase sebesar $32,35 \%$. Data tersebut menunjukkan bahwa pencapaian hasil belajar peserta didik yang dibelajarkan menggunakan model Problem Based Learning lebih tinggi dibanding peserta didik yang dibelajarkan menggunakan model Discovery Learnin. Rendahnya persentase ketuntasan hasil belajar peserta didik di kelas ekperimen II disebabkan masih adanya kekurangan selama proses pembelajaran berlangsung.

Model PBL yang digunakan di kelas XI MIA 3 dan model Discovery Learning yang digunakan di kelas XI MIA 6 dalam pelaksanaanya, seluruh peserta didik mengikuti tahapan pembelajaran secara serius berdasarkan sintaks kedua model yang membuat peserta didik aktif dalam setiap fase pembelajaran. Tahap pertama sintaks PBL yaitu orientasi masalah kepada peserta didik, dimana peserta didik diberikan fakta-fakta tentang sifat-sifat larutan asam-basa sehingga peserta didik mampu mendeskripsikan teoriteori asam-basa dengan menentukan sifat larutan dan menghitung $\mathrm{pH}$ larutan. Peserta didik diajak memahami permasalahan tersebut, sehingga timbul rasa penasaran peserta didik. Begitu juga pada tahap pertama model Discovery yaitu pemberian stimulus pada peserta didik sehingga muncul rasa penasaran dalam menanggapi stimulus yang diberikan, Hal ini sesuai yang disampaikan oleh Widiadnyana (2014) bahwa timbulnya sikap keingintahuan untuk menyelidiki sendiri dan tuntunan eksplorasi, maka akan mengarahkan pemikiran peserta didik untuk memahami terutama tentang permasalahan yang menjadi topik pembelajaran. 
Perbedaan Hasil Belajar Peserta Didik Kelas XI MIA SMAN 9 Gowa yang diajar Model Problem Based Learning dan Discovery Learning (Studi pada Materi Pokok Asam Basa)

Pada model PBL peserta didik mulai memikirkan adanya suatu masalah tertentu mengenai materi asam-basa. Beberapa peserta didik mulai memberikan pendapatnya yaitu dengan memberikan penjelasan sederhana tentang sifat-sifat larutan asam basa. Serta menyampaikan rumusan masalah yang timbul dari faktafakta itu, kemudian peserta didik diarahkan membuat hipotesis dari rumusan masalah yang ajukan. Begitupun pada model Discovery tahap mengidentifikasi masalah, peserta didik diberikan tanggung jawab untuk menemukan atau mengidentifikasi masalah berdasarkan indikator pembelajaran. Saat mengidentifiikasi masalah timbul rasa ingin tahu pada peserta didik terhadap teori-teori yang dijadikan dasar dalam menentukan sebuah masalah. Hal ini didukung oleh penelitian yang dilakukan oleh Patrianingsih (2016) bahwa pada sintaks problem statement, peserta didik merasa penasaran akan kebenaran hipotesis yang dirumuskan.

Selama proses pembelajaran peserta didik dikelompokkan secara heterogen dan dibagikan LKPD. Tahap selanjuntnya pada model PBL yaitu melakukan penyelidikan dan penyelesaian masalah. Peserta didik bersemangat mencari informasi, ada yang membaca buku, mencermati LKPD dan berdiskusi dengan teman kelompoknya. Setelah itu peserta didik diarahkan untuk menjawab pertanyaanpertanyaan pada LKPD yang menghubungkan antara hasil penyelidikan yang dilakukan dengan masalah yang diberikan. Pertanyaan ini diajukan agar peserta didik memikirkan tentang kelayakan hipotesis dan metode pemecahan masalah serta kualitas informasi yang mereka kumpulkan (Ibrahim \& Nur, 2005). Sehingga peserta didik dapat terarahkan dalam pencarian informasi yang dibutuhkan untuk memecahkan masalah. Sedangkan tahap selanjutnya pada model Discovery yaitu mengumpulkan dan mengolah data, peserta didik bersemangat mencari sumber pembelajaran ada yang membaca buku, mencermati LKPD dan berdiskusi dengan teman kelompoknya. Namun dalam pengerjaan LKPD terdapat beberapa pemecahan masalah yang keluar dari indikator permasalahan, terlihat peserta didik masih ada yang bingung menyusun penemuannya. Sehingga pada model Discovery ini menunjukkan masih kurangnya kemandirian pesera didik kelas XI MIA SMAN 9 Gowa dalam melakukan penemuan pemecahan masalah.

Selanjutnya pada model PBL dan Discovery guru mengevaluasi peserta didik, selama tahap ini guru meminta peserta didik melakukan rekontruksi pemikiran dan aktivitas mereka selama tahap pembelajaran yang dilewatinya. Kapan mereka pertama kali memperoleh pemahaman yang jelas tentang situasi masalah? Kapan mereka merasa yakin dalam pemecahan masalah? Setelah guru melontarkan beberapa pertanyaan tersebut, peserta didik yang menggunakan PBL menanggapi bahwa mereka baru memperoleh pemahaman tentang situasi masalah ketika melakukan penyelidikan mengenai pemecahan dari situasi masalah tersebut. Pemberian pertayaan- 
Perbedaan Hasil Belajar Peserta Didik Kelas XI MIA SMAN 9 Gowa yang diajar Model Problem Based Learning dan Discovery Learning (Studi pada Materi Pokok Asam Basa)

pertanyaan oleh guru pada tahap pemecahan masalah mengarahkan peserta didik untuk menemukan infomasi yang dibutuhkan dan menghubungkan masalah yang dirumuskan sebelumnya. Sedangkan peserta didik yang menggunakan model Discovery menanggapi bahwa mereka baru memperoleh pemahaman tentang situasi masalah ketika melakukan pengumpulan data. Peserta didik secara mandiri dapat menerima sejumlah informasi untuk memecahkan masalah. Namun dalam pengerjaan LKPD terdapat beberapa pemecahan masalah yang keluar dari indikator permasalahan dan juga terlihat peserta didik masih ada yang bingung menyusun penemuannya.

Pada kegiatan akhir, setiap peserta didik menyimpulkan hasil pembelajaran, guru mengumpulkan lembar kerja peserta didik, memberikan soal evaluasi dan menyampaikan materi yang akan dipelajari pada pertemuan berikutnya

Data yang didapatkan dijadikan dasar bahwa model pembelajaran PBL lebih efektif digunakan untuk pembelajaran kimia pokok bahasan asam basa. Hal ini disebabkan karena model pembelajaran PBL lebih terfokus bagaimana peserta didik terampil dalam mencari informasi penting yang dapat mendefinisikan pemecahan masalah secara jelas. Sedangkan melalui model pembelajaran Discovery penekanan pada konsep penemuan peserta didik terkadang menimbulkan kebingungan antar peserta didik bagaimana menyusun pengetahuannya. Apalagi ketika peserta didik tidak memiliki kepercayaan diri untuk menyelsaian masalah maka sulit untuk peserta didik melakukan penemuan.

Berdasarkan analisis data yang telah di lakukan setelah di lakukannya penelitian yang telah di paparkan data uji normalitas menunjukkan bahwa data yang di dapatkan dari kedua kelas experimen tidak normal sehingga digunakan uji Man-Whitney. Uji homogenitas data yang di dapatkan tergolong homogen antar 2 kelas yang di jadikan subjek komparasi. Uji hipotesis pada analis data memberikan keputusan dimana $\mathrm{H}_{1}$ diterima yang berarti terdapat perbedaan hasil belajar antara peserta didik yang diajar menggunakan model pembelajaran Problem Based Learning (PBL) dan model pembelajaran Discovery Learning pada pembelajaran kimia pokok bahasan asam basa.

Dari hasil penelitian model PBL menujukkan pencapaian hasil belajar yang lebih tinggi dibandingkan model Discovery Learning. Namun tingkatan kognitif peserta didik kelas XI MIA SMAN 9 Gowa menggunakan kedua model ini hanya pada tingkatan materi yang bersifat teori atau hafalan. Sedangkan untuk kemampuan perhitungan dan analisis peserta didik dinilai masih kurang. Hal ini menujukkan peserta didik belum mampu untuk berpikir kritis dengan menggunakan model PBL dan Discovery Learning.

\section{KESIMPULAN DAN SARAN}

\section{A. Kesimpulan}

Berdasarkan analisis data dan pengujian hipotesis yang di lakukan maka dapat ditarik kesimpulan bahwa 
Perbedaan Hasil Belajar Peserta Didik Kelas XI MIA SMAN 9 Gowa yang diajar Model Problem Based Learning dan Discovery Learning (Studi pada Materi Pokok Asam Basa)

terdapat perbedaan hasil belajar antara peserta didik yang diajar menggunakan model Problem Based Learning dan peserta didik yang diajar dengan model Discovery Learning pada pembelajaran kimia materi pokok asam basa

Dari hasil penelitian model PBL menujukkan pencapaian hasil belajar yang lebih tinggi dibandingkan model Discovery Learning. Namun tingkatan kognitif peserta didik kelas XI MIA SMAN 9 Gowa menggunakan kedua model ini hanya pada tingkatan materi yang bersifat teori atau hafalan. Sedangkan untuk kemampuan perhitungan dan analisis peserta didik dinilai masih kurang.

\section{B. Saran}

Berdasarkan penelitian yang telah di lakukan maka peneliti ingin mengemukakan beberapa saran yaitu

1. Bagi guru, penelitian ini dapat menjadi rujukan untuk menggunakan model pembelajaran Problem Based Learning pada materi asam basa.

2. Bagi peneliti selanjutnya, mencoba mencarikan solusi untuk model Problem Based Learning dan Discovery Learning agar dapat meningkatkan kemampuan perhitungan peserta didik.

\section{DAFTAR PUSTAKA}

Ibrahim dan Nur. 2005. Pengajaran Berdasarkan Masalah. Surabaya: University Press

Mangun, Sigit Wardoyo. 2013. Pembelajaran Berbasis Riset. Jakarta: Akademia Permata

Patrianingsih, Endang Ayu dan Ernawati S. Kaseng. 2016. Model
Pembelajaran Discovery Learning, Pemahaman Konsep Biologi, dan Sikap Ilmiah Peserta Didik. Jurnal Penelitian Pendidikan INSANI, Volume 19, Nomor 2, Desember 2016.

Uno, Hamzah dan Nurdin Mohammad, 2011. Belajar dengan Pendekatan PAILKEM. Jakarta: Bumi Aksara.

Widiadnyana, I Wayan, dkk. 2014. Pengaruh Model Discovery Learning terhadap Pemahaman Konsep IPA dan Sikap Ilmiah Siswa SMP. Jurnal Program Pascasarjana Universitas Pendidikan Ganesha Program Studi IPA. Volume 4, Tahun 2014. 